\title{
“More Confident Going into College": Lessons Learned from Multiple Stakeholders in a New Blended Learning Initiative
}

\author{
Aimee L. Whiteside, Ph.D. \\ University of Tampa \\ Amy Garrett Dikkers, Ph.D. and Somer Lewis \\ University of North Carolina Wilmington
}

\begin{abstract}
This article examined a blended learning initiative in a large suburban high school in the Midwestern region of the United States. It employed a single-case exploratory design approach to learn about the experience of administrators, teachers, students, and parents. Using Zimmerman's Self-Regulated Learning (SRL) Theory as a guiding framework, this study explored surveys, face-to-face observation data, interview transcriptions, and focus group transcriptions to learn about different stakeholders' experiences and their observations about student readiness for blended learning. As a result, the data suggested three major themes, namely how blended learning initiatives can promote autonomy and self-regulation, encourage inquiry and build relationships, and ultimately help students feel ready for college.
\end{abstract}

Keywords: self-regulated learning, blended learning, K-12 education, case study research

\section{Introduction}

The concept of school is rapidly changing at the secondary school level. External forces and technological advancements are changing the face of education. Our K-12 schools are often under fire for lack of diverse instructional strategies, (over) testing our youth, and inadequate college preparation (Cole, 2008). 
While traditional notions of schooling have long privileged core academic content taught in a face-to-face setting, recent research points to the rise of student success in multiple modalities, resulting in increased motivation, time management skills, and self-regulation aptitude (Moore, 1997; Zimmerman, 2000, 2002; Garrison \& Kanuka, 2004). The Clayton Christensen Institute for Disruptive Innovation (2016), a nonprofit think tank devoted to exploring the transformational power of disruptive innovation, provides the most comprehensive and perhaps best-known definition of blended learning, stating: "Blended learning involves leveraging the Internet to afford each student a more personalized learning experience, including increased student control over the time, place, path, and/or pace of learning” (n.p.). As blended learning initiatives continue to grow (Allen \& Seaman, 2015), the challenge for K-12 is learning how students adjust to and thrive in multiple modalities and how to best support and guide their learning.

\section{Literature Review}

Although blended learning in K-12 schools and districts is increasing and researchers are projecting continual growth in K-12 blended learning, empirical research on blended learning in the K-12 environment continues to be limited (Halverson, Graham, Spring, \& Drysdale, 2012; Means, Toyama, Bakia, \& Jones, 2010; Wayer, Crippen, \& Dawson, 2015). In their analysis, Halverson, et al. (2012) found only 1.8\% of publications in top-cited articles, chapters, books, and journals between 2001 and 2011 focused on blended learning specifically in K-12 settings. Recent meta-analyses of the research literature and reports of blended learning support the value of blended learning to reach the needs of a variety of K-12 students (Means, Toyama, Murphy, Bakia, \& Jones, 2010; Powell et al., 2015; Wayer et al., 2015), yet recognize that the research is limited to student outcomes and does not thoroughly analyze or evaluate teacher preparedness and blended learning course and program development.

Some researchers who have attempted to analyze the impact of certain blended learning pedagogical techniques on student learning have found mixed results and, instead, discuss implications of their research for program implementation or instructional strategies (Lee, Yeh, Kung, \& Hsu, 2007; Pace \& Mellard, 2016). Other researchers find promise in particular areas. For example, experts Shea and Bidjerano suggest that blended learning courses, programs, and initiatives offer a unique opportunity for students to enhance their "learner presence” (2010).

Powell, et al.’s (2015) examination of blended learning over the previous seven years discussed seven different models of blended learning, aligning these with the work of the Clayton Christensen Institute. Across the exemplary models, four key elements emerged: the importance of school culture; an awareness of blended learning goals and benefits; an examination of professional development (also explored in Lewis \& Garrett Dikkers, 2016; Parks, Oliver, \& Carson, 2016); and the importance of addressing barriers for implementation (also explored in Riel, Lawless, \& Brown, 2016).

Overall, the literature regarding the value of individualized blended and online learning merges with the Christensen's definition and personalized learning for K-12 students. This blend involves a focus on a more personalized learning experience (Smith \& Bashan, 2014) that allows students the opportunity to gain vital skills in regulating their own learning in a blended learning 
context (Barnard, Lan, To, Paton, \& Lai, 2008). This integration among blended learning, personalized learning experiences, and learner self-regulation creates the foundation for the current study. To this end, this study examines a new blended learning initiative, as detailed in the next section, through the lens of self-regulated learning.

\section{Context of the Case}

This study examines a blended learning initiative in a large suburban high school in the Midwestern region of the United States. This high school had grown in population from about 400 students in the mid-1990s to about 2,500 students in Spring 2014, when we collected data for the current project. The initiative started with three blended classes in the 2011-2012 school year and increased offerings to seventeen classes with twenty-one teachers and a total of 835 seats in the 2013-2014 school year (Garrett Dikkers, Whiteside, \& Lewis, 2014, 2017).

The leadership's move to blended learning was a response to rapid growth as well as the district's desire to prepare their students for twenty-first century digital skills and collegiate studies. The district and its teachers values a strong student-teacher relationship as well as consensus from a close, interactive group of teachers and administrators (Garrett Dikkers, et al., 2014, 2017). In 2011-2012, the academic leadership strategically began a blended learning initiative that runs simultaneously with their traditional face-to-face courses, beginning with a pilot of three classes. Three key features of this program render it unique, including: (a) careful planning and designing of a teacher-generated curriculum by self-selecting teachers, (b) purposeful scheduling of face-to-face and blended options at the same time, and (c) the addition of a new concept called flex time, which allows students flexibility in how they use the time that would have been designed for class. During their flex time, students are working on class activities in the online environment, engaging in class-related peer activities, meeting with teachers, or other activities of their choice.

Key school leaders purposely chose not to engage with an outside vendor for curriculum and instead focused on a community-based, teacher-generated approach to curricular design. At the onset of the program, the teachers self-selected into the initiative, designing a mix of several required and elective coursework, including advanced placement courses. Additionally, many of these teachers taught the same content in a blended class section alongside a traditional class section, which allowed students the flexibility of moving back into a face-to-face class if they were struggling with the content or disliked the blended delivery method.

The blended class offerings varied widely in instructional approaches, including use of discussion boards, wikis, and other elements of their learning management system, Haiku. Some examples of teachers and students utilizing technology in their face-to-face meeting times were taking online quizzes, adding content to a course wiki, accessing course materials through the Haiku site, or using iPads and Google Chromebooks for other content-based learning.

Courses met face-to-face two or three times a week versus every school day, and the remainder of student work and collaboration was completed in the Haiku learning management system. Instead of employing traditional lesson plans, many teachers taught these lessons, yet grew to rely on a balance of mastery learning and individualized support. Students worked at 
their own pace with or without the help of teachers during their flexible time (flex time), or time not in the face-to-face classroom. This built-in flex time for students offered a unique aspect where students could meet with their teacher individually for further enrichment, meet with other content area instructors, utilize online resources, or work collaboratively with peers (Garrett Dikkers et al., 2014, 2017).

In terms of teacher support, the Blended Learning Director mentored instructors one-onone as needed and convened regular workshop sessions in which all the current blended learning instructors discussed pathways to meet students' needs, shared instructional strategies, and explored software solutions across the disciplines.

Overall, this case study research seeks to learn more about the experiences of all key stakeholders, administrators, parents, students, and teachers, in regard to the blended learning initiative which aimed to provide students a gateway to technology-enhanced learning and college readiness. Our specific research question was as follows: What are the experiences of the four key stakeholder groups (administrators, parents, students, and teachers) in this blended learning initiative in relation to self-regulated learning?

\section{Theoretical Framework}

As a guiding framework, this study employs Zimmerman's (1990, 2000, 2002) SelfRegulated Learning (SRL) Theory. Self-regulated learning refers to the understanding of one's own methods, progress, and end-goals when acquiring a certain knowledge or skill. In other words, a certain knowledge or skill is desired to be learned by an individual so that individual monitors him/herself throughout the journey toward that knowledge and adjusts accordingly along the way (Weimer, 2009). Because concepts such as "knowledge” and "education" exist upon a spectrum, the theory of self-regulated learning describes a continuous process. It is a cycle that the learner never truly abandons. Zimmerman (2002) coined the term self-regulated learning (SRL) not as "mental ability or an academic performance skill," but "rather...[a] selfdirective process by which learners transform their mental abilities into academic skills” (p. 65). SRL encourages the learner to plan, monitor, and complete a task based on goals, objectives, and instructions received (Effeney, Carroll, \& Bahr, 2013; Hattie, 2013; Nicol \& Macfarlane-Dick, 2006; Picciano, 2002; Picciano \& Seaman, 2009, 2010; Pintrich \& Garcia, 1994; Pintrich \& Zusho, 2002; Ryan \& Deci, 2000; Schunk \& Ertmer, 2000; Zimmerman 2000, 2002).

The SRL perspective engages three specific phases of students' learning processes: Forethought, Performance, and Self-Reflection Phases (See Figure 1). Forethought relates to goals, objectives, and planning a learning task. Performance consists of monitoring and completing the task, as well as the students' sense of self-efficacy and autonomy, and the SelfReflection Phase involves reflecting on the experience and learning from failure and smaller mistakes. 


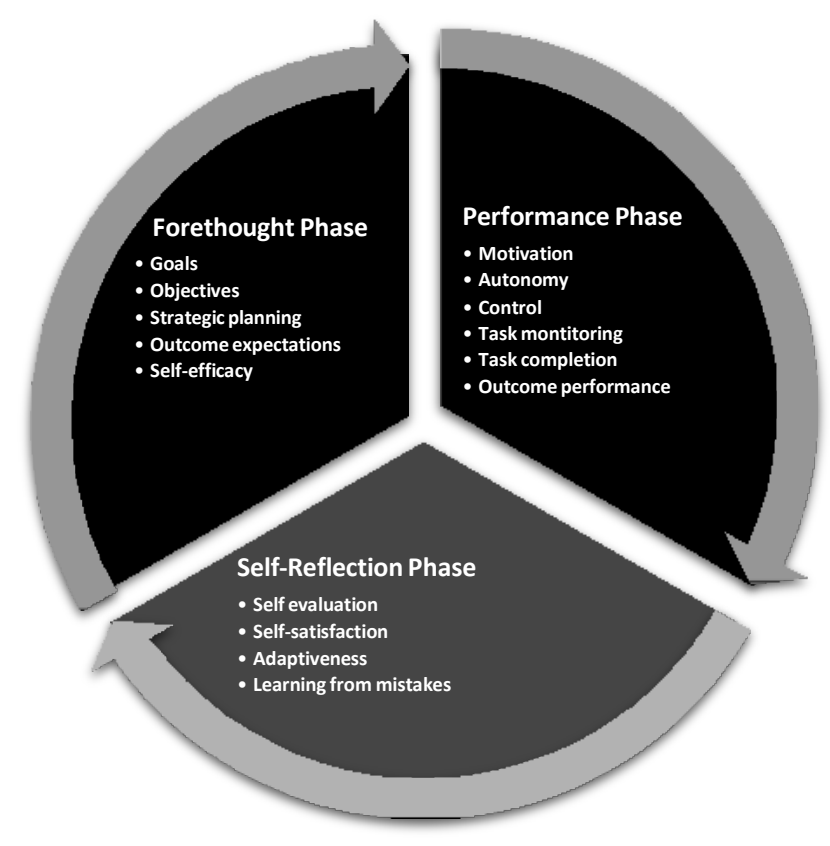

Figure 1. Zimmerman's Self-Regulated Learning. Original graphic, information adapted, in part, from: "Becoming a self-regulated learner: An overview,” B. Zimmerman, 2002. Theory into Practice, 41(2), p. 67.

Zimmerman and his colleagues focused much of their research on specific instances of knowledge to rectify the problem of having to study an individual's entire learning career. The process of self-regulated learning involves cognitive abilities to recall and retain information, metacognitive abilities to understand one's own processes of learning, and the motivation to continually monitor both and adjust as necessary (U.S. Department of Education, Office of Vocational and Adult Education, 2011). In practice, SRL can transform otherwise rote learning into "an activity that students do for themselves in a proactive way rather than a covert event that happens to them in reaction to teaching” (Zimmerman, 2002, p. 65).

Self-regulated learning is best defined as an existing process of knowledge acquisition rather than a pedagogical tool. While researchers in the field of education and education psychology have delineated the components of self-regulated learning, they also understand that a self-regulated learner is motivated by his/her own personal end-goals, that this theory is merely a description of one type of successful learning (Zimmerman, 1990). One can be taught to monitor himself as he learns, to set goals along the way, and to revamp those goals when necessary. Self-regulated learning is utilized best when a student's innate mental capabilities, his/her understanding of agency, and his/her level of self-awareness are well ordered and well oiled. Additionally, Zimmerman (2002) suggests, "[S]elf-regulated students are not only more likely to succeed academically but to view their futures optimistically" (p. 66).

SRL in blended learning has come of age with new findings and measurements in higher education (Barnard, Lan, To, Paton, \& Lai, 2008; Lee, Shen, \& Tsai, 2010; Orhan, 2007). This particular study aims to extend our understanding of SRL in another blended learning context at the programmatic and secondary school levels. 
The research questions are as follows:

- To what extent, if any, does blended learning coursework help students regulate their own learning?

- What is the experience of different stakeholders (administrators, parents, students, and teachers) in a relatively new blended learning initiative?

\section{Methods}

This study employs a single-case, exploratory design approach to explore the experience of multiple perspectives in regard to a blended learning initiative in a Midwestern high school in the United States (Yin, 2009). Since the literature points to survey methods as the best approach for mid- to large-sized populations (Babbie, 1973), in Spring 2014, we first designed and delivered a series of surveys for each stakeholder group (administrators, teachers, students, and parents) with a mix of demographic, closed-choice, Likert-scale, and open-ended questions. At the midterm in March 2014, we observed face-to-face class sessions of ten different blended learning classes as well as reviewed course sites and district information about their blended learning initiative. Additionally, we conducted interviews $(n=9)$ and focus group sessions $(n=8)$ based on scheduling constraints and availability. This study analyzes and synthesizes data to understand more about the specific experiences of administrators, parents, students, and teachers in this education endeavor. Table 1 provides a breakdown of data collection methods.

Table 1

Data Collection Methods

\begin{tabular}{|c|c|c|c|c|c|}
\hline & Surveys & Interviews & Focus Groups & $\begin{array}{l}\text { Classroom } \\
\text { Observations }\end{array}$ & $\begin{array}{l}\text { Course sites and } \\
\text { materials }\end{array}$ \\
\hline Leaders & $n=5$ & $\mathrm{n}=6$ & -- & -- & $\begin{array}{l}\text { Publicity, } \\
\text { marketing, and } \\
\text { presentation } \\
\text { materials from } \\
\text { the school and } \\
\text { district }\end{array}$ \\
\hline Teachers & $\mathrm{n}=18$ & $n=1$ & $\begin{array}{l}2 \text { groups } \\
(n=17)\end{array}$ & $\mathrm{n}=10$ & $\begin{array}{l}\text { Haiku sites for } \\
2 \text { courses }\end{array}$ \\
\hline Students & $n=264$ & -- & $\begin{array}{l}6 \text { groups } \\
(n=26)\end{array}$ & -- & $\overline{--}$ \\
\hline Parents & $n=62$ & $n=2$ & -- & -- & -- \\
\hline
\end{tabular}

We employed elements of an existing Self-Regulated Learning (SRL) coding scheme (Effeney, Carroll, \& Bahr, 2013) and added our own emergent coding. The emergent coding process was based on the unique needs of the case study with codes for each stakeholder group. We also wanted to get a sense of how ready students felt in joining in a blended learning initiative ("blended readiness") as well as whether SRL-related competencies made students feel a sense of readiness for college-level work ("college readiness"). Therefore, we coded for themes related to the SLR framework, such as self-evaluation, self-regulation, seeks assistance, blended readiness, and college readiness (See Appendix A for the Coding Scheme). Over eighty percent of the data was coded by two coders who were provided an hour-long introduction to the concept 
of self-regulated learning, to the context and purpose of the study, and to the coding scheme. Agreement between the coders was $97.81 \%$. Since chance can play a role with two coders, we also employed Cohen's kappa, which is a reliability measurement ranging from 1 to 0 , where 1 is perfect agreement. The Cohen's kappa for our coding was .8041, which falls into the excellent range (Cicchetti, 1994). Additionally, Appendix B provides a few examples of the coding.

In reflecting on the validity and reliability of our methods, one major strength of this study is the multiple data sources - surveys, interviews, and focus groups-for the four different stakeholder audiences. Another strength of our methods was the emergent codes for blended readiness and college readiness, which helped us understand the students' self-reflections on their personal readiness to undertake a blended learning course and their assumptions and perceptions about their level of college readiness after the high school blended learning experience.

\section{Limitations}

Although we learned a great deal of information from the four stakeholders in this study, we faced a number of limitations. One limitation of our methods includes the dearth of specific codes and questions directed toward students planning and task analysis within SLR's Forethought Phase. Also, because of the shifting nature of how many stakeholders participated in the blended learning initiative at any given time, we experienced great difficulty in getting concrete numbers on precise total numbers of participants to provide accurate response rates. It also proved difficult to get ongoing access to the online coursework. That said, we gained considerable data from the four stakeholders (administrators, parents, students, and teachers).

\section{Results}

The four different stakeholder groups in this study gave a unique insight into understanding how self-regulated learning within a blended learning program may benefit learners. We discuss key points from each stakeholder group in this section.

\section{Administrators}

Administrators at this school $(n=5)$ commented often on the Task Analysis and the SelfReflection Phases of Self-Regulated Learning Theory, often expressing their deep value for learner-centered pedagogy, innovative instructional practices, community-based decisions, and relationships. The superintendent suggested

I think that the student-teacher relationship is still so important.... A lot of what kids learn in high school is not just the curriculum; it's their learned development as a person. And that's where teachers and coaches and everybody is [sic] critical to that.

Another administrator noted, "Teachers tell me that they are appreciative for what blended [learning] has forced them to do as an educator. It has reinvigorated them and reinvented their teaching approach.” Another suggested

I have been surprised by the level of appreciation that our students are showing for the blended offerings...Most surprising is the positive feedback that students feel that they 
are closer to their teachers in the blended model, due to the frequent email/Haiku communications, as well as the small group discussions that are available on non-meeting days.

Administrators clearly value the relational aspect of this blended model, its impact on students' ability to self-regulate, and the positive effect on teachers.

\section{Parents}

In contrast to school administrators, parents $(n=62)$ provided insight on their observations of their children in the Performance and Self-Reflection Phases of the process. The data suggest that many parents surveyed believe blended learning experiences for their children have been valuable. Over $60 \%$ of parents responding to the survey $(n=31)$ believed it was very important or important that their children had the opportunity to participate in blended learning classes. Parents responding to the survey also overwhelmingly agreed $(54 \%, \mathrm{n}=54)$ or strongly agreed $(36 \%, n=18)$ that blended learning courses were a nice transition to college for their students. One parent explains how her son's blended learning will help him in college. She addressed her gratitude that her son is hitting those "bumps in the road" of managing his time and being responsible for his own learning in high school, where he still has immediate support from his teachers and family.

Several parents mentioned appreciating the fact their "children are allowed to progress at their own pace," as well as blended learning's potential to "fuel their want and need to learn." Additionally, parents indicated they "enjoy seeing the district trying other education forms" as well as offering both formats simultaneously. One parent noted, "My child is more satisfied with his overall high school experience. He has the time in school to complete assignments and shows the responsibility to manage his time. It's a win..win..win in our house.” The majority of parents believed blended learning helped their students with time management skills $(27.45 \%, n=14$, strongly agreeing and $58.82 \%, \mathrm{n}=30$, agreeing). Parents also strongly agreed $(26.53 \%, \mathrm{n}=13$ ) or agreed $(48.98 \%, n=24)$ that blended learning prompted their child to take more responsibility for his/her learning.

Parents also mentioned several concerns. Like teachers, they expressed concerns about training and readiness for a blended approach as well as their child's use of the flex time. Some parents noted that it's an added stressor to "already busy schedule[s]" for advanced students; one parent also noted that it may not be the best fit for students with disabilities. Other parents expressed concerns about technology integration practices, reduced quality family time, and deadline conflicts with activities. Their concerns align with the Performance Phase of SRL, specifically related to control, autonomy, and motivation.

\section{Students}

Like their parents, students $(n=264)$ focused mostly on the Performance and SelfReflection Phases of Self-Regulated Learning Theory. Out of the students surveyed who had stated they had completed a blended learning class, most preferred blended learning. Only 10.8\% $(\mathrm{n}=18)$ preferred traditional face-to-face classes. The remaining students had no preference or hadn't yet completed the blended class(es) they were taking. Figure 2 addresses students' course delivery preferences. 


\section{If you have completed at least one blended class, please indicate which format you prefer}

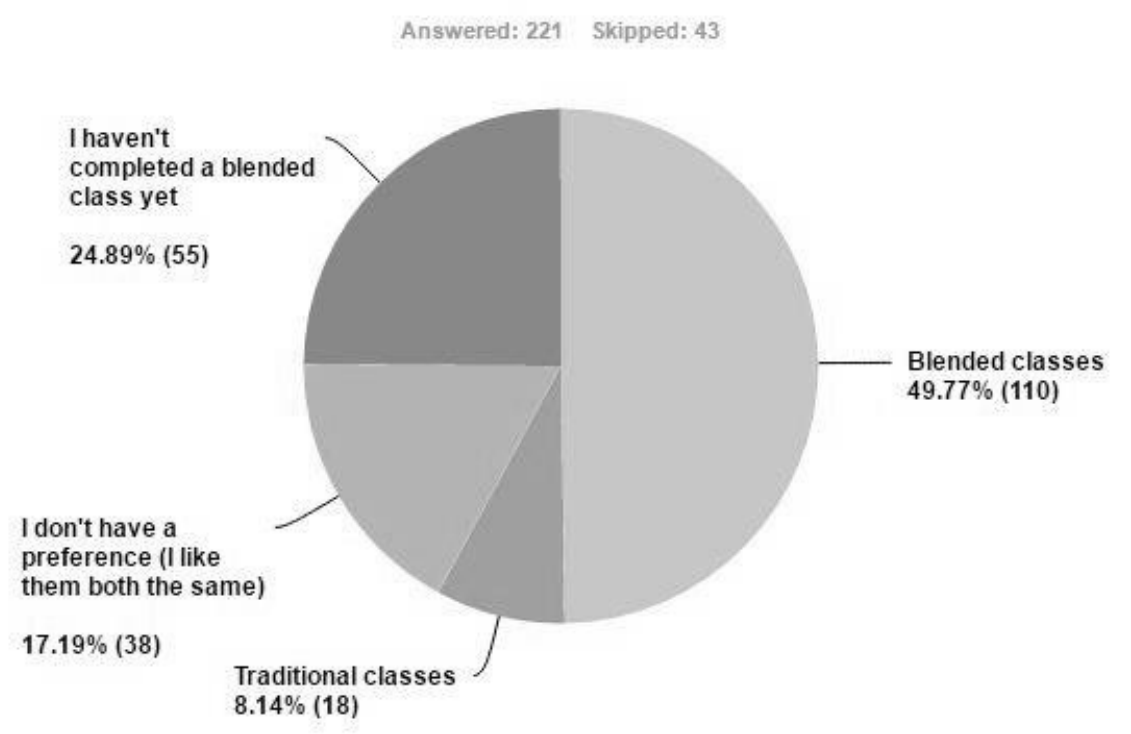

Figure 2. Student Delivery Preferences

Students overwhelmingly stated they felt like they had more control over their learning in a blended class $(40.84 \%, \mathrm{n}=107$, strongly agreeing with that statement and $48.85 \%, \mathrm{n}=128$, agreeing with that statement). Students also believed blended learning required them to take more responsibility for their own learning than their traditional high school classes $(53.44 \%, \mathrm{n}=$ 140 , strongly agreeing with that statement and $39.31 \%, \mathrm{n}=103$, agreeing with that statement). Comments from many students in focus groups demonstrate self-actualization, as they discuss their experiences in blended learning and what they learned about themselves. Representative quotes include the following:

- "If I don't learn something, it's nobody's fault but my own because I had all the resources available to me."

- "You have to be very self-aware to take a blended class...you need to know more about yourself in order to take a blended class."

- "I like the idea, but it's not really for me."

- "That's why I took this class...I wanted to prepare myself for the future."

- "Yeah, I feel like it really benefits especially if you're a junior or a senior taking blended courses...you're really getting prepared for how college life is going to be. I think that's a big benefit.”

- "I struggle in math; there's no way I could ever take a blended math class. I need a teacher to be there explaining the lesson to me.” 
Student participants discuss blended learning as helping them manage their time, forcing them to take responsibility, allowing them to identify how they learn best, and helping them gain study habits they need to be successful in college. One student commented that "the days off let me [study] AP psych at home where I have access to technology and a peaceful work environment." Another student noted, "Blended learning has taught me to take responsibility for my learning. It's helped me a lot with time management." Students also address technology literacy and communication. One indicated, "I learned a lot more than I thought I would...I also have developed a better sense of how to communicate efficiently with others through technology."

Students often noted blended learning as preparing them for college. One student explained, "That's actually why I took this class ... [be]cause I wanted to prepare myself for the future where I'd be on my own and having to manage my time properly...[to] feel a little more confident going into college."

\section{Teachers}

Teachers $(n=18)$ are the stakeholder group in this study that carefully saw the initiative from the early planning stages, and they provide ample feedback on their students' continual self-regulated learning growth (as well as their own). The data suggests that a few teachers saw themselves as pioneers and had a strong sense of pride for overcoming pressures to bond together as a community to serve their students well. One teacher noted, "We were the guinea pigs, so we had to work through some problems and solve them together which helped build a strong relationship.” Teachers designed their own curriculum and used the face-to-face time for enrichment activities that build on what the students have worked on individually outside of class.

This shift in modalities also created a shift for teachers' pedagogies and strategies, as they have to move from being the keeper of all knowledge for their high school students to the facilitator who aids the students in gaining that knowledge through less traditional means. Some teachers struggled at first to let go of these traditional roles. Other teachers found this shift began impacting their traditional classes, causing them to bring technology into those classes and change their instructional practices.

The district superintendent explains this shift and the impact of blended learning on teachers and their own subsequent growth in self-regulation:

It's as much about the teacher learning how to be a 21st century educator...Blended is really serving two purposes for us. It's getting the kids to take ownership of their learning and branch out from the traditional classroom setting, in the 1890s schoolhouse that we all still function in. But it's also creating an avenue for [the administration] to push 21st century teaching and facilitating the classroom instead of being standing in front, "I know all” teacher,

Teachers surveyed confirm that blended learning classes take significantly more time and resources than face-to-face classes, yet they indicated preference in teaching blended classes over traditional classes. Teachers' survey comments also note a strong sense of concern about 
self-efficacy and student readiness for blended learning. Although all teachers believed their blended learning students felt like they had more control over their learning $(58.82 \%, \mathrm{n}=10$, strongly agree and $41.18 \%, \mathrm{n}=7$, agree), and had to take more responsibility for their learning (see Figure 3), teachers do express concerns about whether all students can be successful in blended learning classes.

\section{In this blended class, my students seem to feel like they have to take more responsibility for their learning}

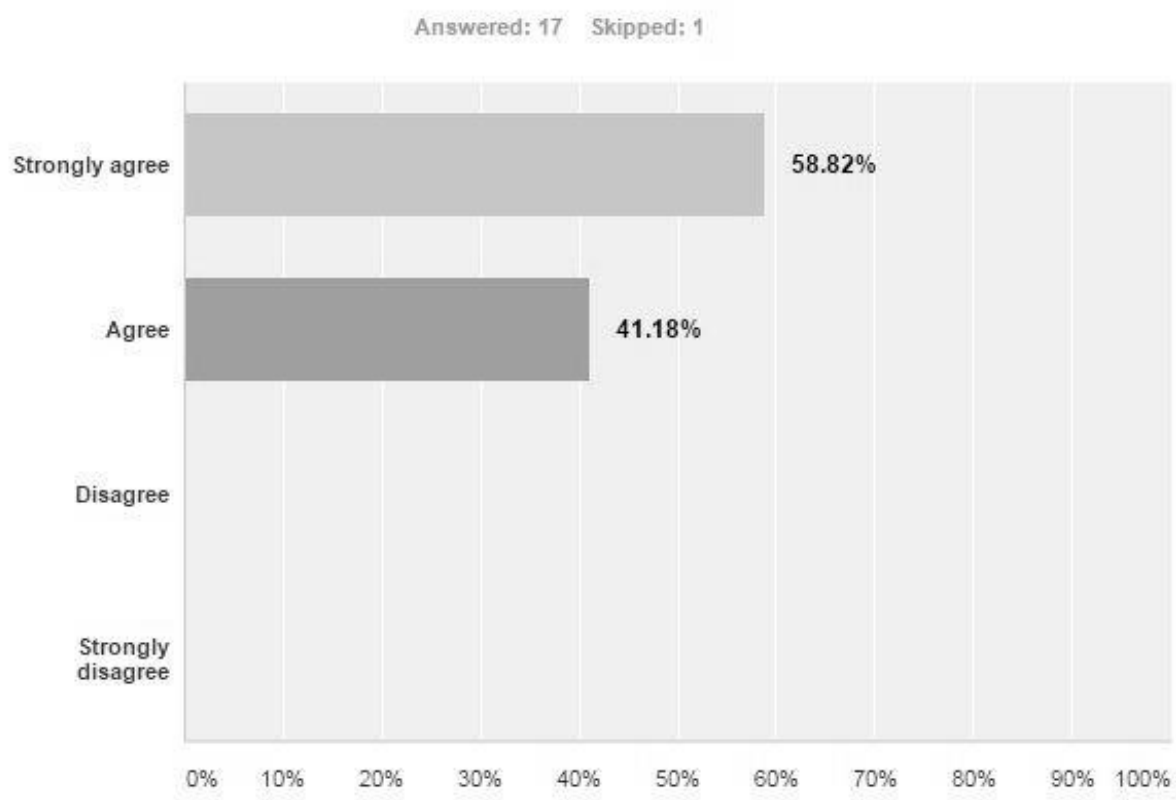

Figure 3. Teachers’ Perceptions of Blended Students’ Self-Regulated Learning

One teacher notes, "I would say that about $60 \%$ feel satisfied since they are capable...The other $40 \%$ seem to struggle because...they do not have the skill sets to be successful on their own. Yet, it pushes them to take responsibility.” Teachers also suggested that both teachers and their blended students ask more questions, invest more in the learning process, and get more out of the learning experience (See Figure 4). 


\section{Usually, when students have questions or problems outside of class time, they seem}

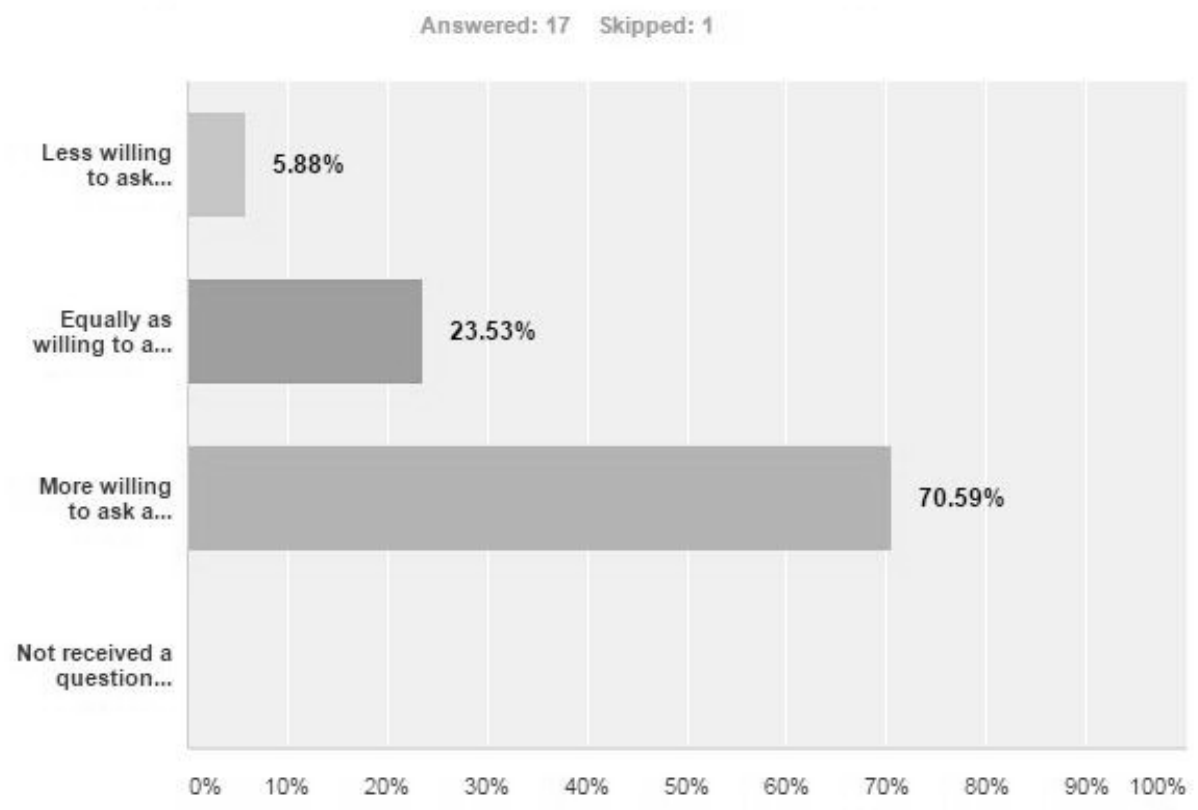

Figure 4. Blended Students’ Willingness to Ask Questions Outside of Class

Most teachers (over 70\%) suggest that students learn as much or more in the blended classes as compared with students in the traditional face-to-face class. This result may relate to how they use their flex time and their growing Self-Regulated Learning (SRL) skill set. As a foreign language teacher explains,

I ha[ve] kids that come in almost every day...because they ask questions or they [say], "Hey can you look at this?" and I feel like I've kind of built a better rapport with my blended kids than I have with my other students.

The blended initiative allows for an individualized, personal learning approach that helps students synthesize the content and focus on critical thinking. Additionally, the majority of teachers agreed $(41.18 \%)$ or strongly agreed $(29.41 \%)$ that their blended students seemed to demonstrate higher levels of self-regulation than their traditional students (see Figure 5). 


\section{Students enrolled in this blended class seemed more capable of self-regulation than students in traditional classes}

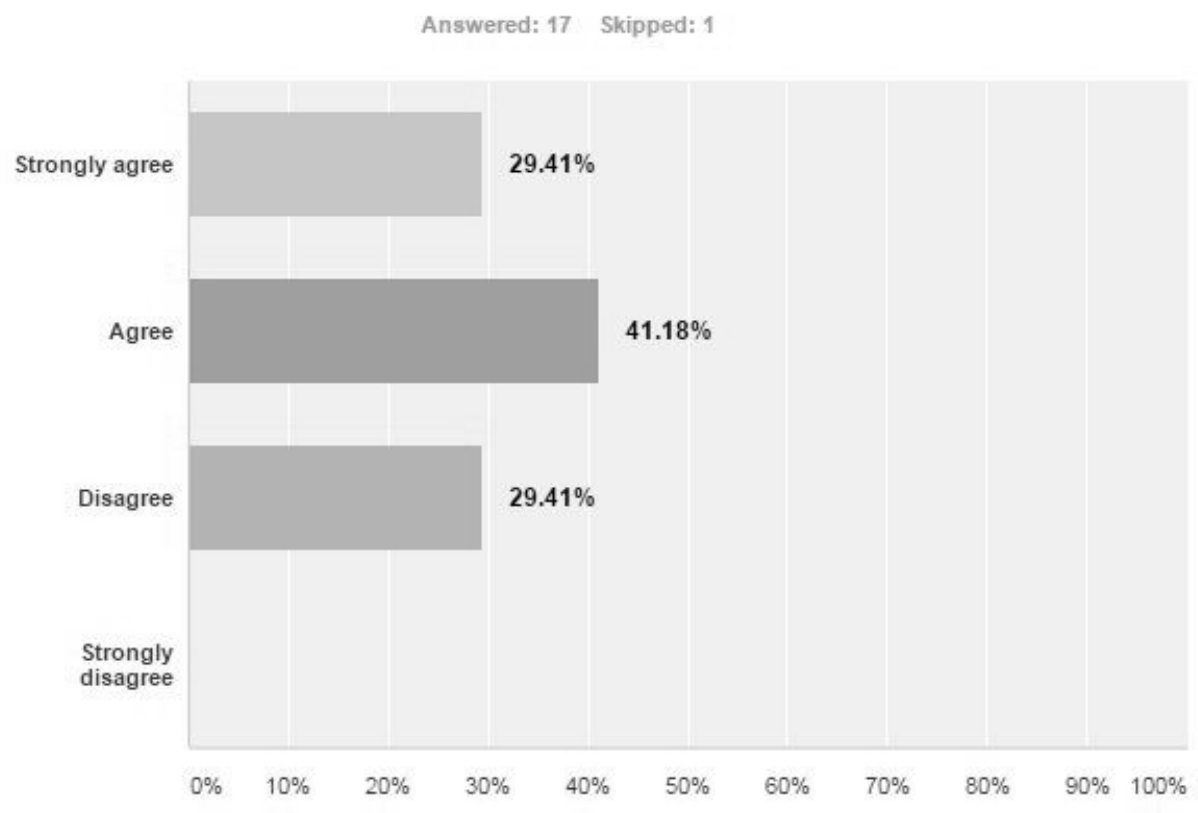

Figure 5. Teacher Perceptions of Self-Regulated Learning for Blended Students

This exploratory study yielded some important findings from the four stakeholders as noted in the next section.

\section{Discussion and Implications}

The data suggests several important implications for schools considering blended learning initiatives. As more students enter higher education having experienced some sort of blended learning experience in their secondary schools and as school leaders seek models for blended learning initiatives (Bestcolleges.com, 2016), this case study offers three main implications for careful consideration:

- Flex time promotes autonomy, self-regulation, satisfaction, and overall learning.

- Blended learning encourages inquiry and builds motivation and relationships.

- Blended learning helps students feel ready for college.

Each of these considerations is discussed in detail below.

\section{Flex Time Promotes Autonomy, Self-Regulation, Satisfaction, and Overall Learning}

A key component of this high school's approach to blended learning allowed for built-in flex time. Flex time is in itself not a new concept, but the sophistication in which it's used in this program promoted a sense of autonomy in students that led to self-regulation, satisfaction, and overall learning. Blended classes met face-to-face two or three times a week, and on the non- 
meeting days, students had flex time. Rather than this flex time being treated as a break, or an "off" day, students were expected to use the flex time for their blended learning coursework, to get one-on-one time with their blended learning teacher, to set up tutoring sessions, and to engage deeper in course content for other classes. They studied in the library, worked from home, met in small groups to work on projects, or even met with teachers. Students, parents, teachers, and administrators all reported this flexibility as a significant benefit, yet stressed the importance of taking precautions for student and building safety.

\section{Blended Learning Encourages Inquiry and Builds Relationships}

With the autonomy and empowerment of flex time, the blended learning experience actually helped students and teachers get to know each other better. Teachers and administrators saw an increase in students reaching out for one-on-one contact with their teachers. Teachers felt a closer and more productive relationship with the students in their blended class(es) because they communicated with them one-on-one more often. Teachers also recognized a depth of learning in some of their blended students that connects more with growth toward independence and becoming accountable for their own learning. Their student began to recognize when they needed assistance from their teachers. One teacher explains: "They are learning how to know when they don't know something. I think that's been really helpful for them. To figure out [when] to come back [to] what questions you know and what questions they need to ask."

\section{Blended Learning Helps Students Feel Ready for College}

Ultimately, many participants in this study discussed an increase in college readiness as a benefit of the blended learning experiences, as well as preparing students for the "complex life and work environments in the 21st century learning." The superintendent emphasized the importance of ensuring that students are ready for college and career, explaining this initiative prepares students to be future professionals by encouraging critical thinking, independent and project management skills. This shift to blended learning required that teachers transition into a facilitator role or "guide-on-the-side role," where students acquire knowledge through less traditional classroom means. With these blended learning opportunities in place providing students some control over time, place, path, and/or pace of their learning, the stakeholders at this school felt that they were truly preparing students for independent learning at the college level. One student noted:

College classes are all structured really similarly to this where you only show up to class two days a week or three days a week and then you do the rest of the work online or outside of class and then you come back to class prepared with everything that you're supposed to have done... so if you're a junior or a senior, you're really getting prepared for how college life is going to be.

\section{Conclusion}

Using Zimmerman's Self-Regulated Learning (SRL) Theory as a guiding framework, this article examined a blended learning initiative in a large suburban high school in the Midwestern region of the United States. It employed a single-case exploratory design approach to learn about the experience of administrators, teachers, students, and parents through surveys, face-to-face observation data, interview transcriptions, and focus group transcriptions to learn about different 
stakeholders' experiences and their observations about student readiness for blended learning. As a result, the data suggested three major themes, namely how blended learning initiatives can promote autonomy and self-regulation, encourage inquiry and build relationships, and ultimately help students feel ready for college. For future research projects, we recommend adding specific codes for motivation and confidence to explore whether students show growth in these areas and whether that growth can be attributed to the specific blended learning situation.

The significance of our work is that it examined one case study from the perspectives of multiple stakeholder groups: students, teachers, administrators, and parents. Also, with a few notable exceptions, each audience seemed to be satisfied with the initiative and what it offered students. The most notable result is the importance of a dedicated cadre of leaders who individualized student learning and helped their students to transition into higher education using SRL and innovative instructional strategies. This quote from one of the administrators exemplifies how this opportunity has allowed the community to bond together to help teachers employ best practices to help their students succeed:

Through blended learning, I have experienced a great deal of anecdotal evidence that blended is good for students. Blended learning has helped me as an administrator have direct insight into student motivation and learning patterns I would not have seen before. In addition, it has helped me guide teachers along best practice for teaching as the mitigating factors which often muddy the water for teachers trying to determine why students aren't succeeding.

In closing, we know that students need far more than core academic subject knowledge to succeed academically and professionally (Wolters, 1999). Research tells us that confidence, mindset, self-efficacy, perseverance, and grit can play a vital role in students' academic success, as does self-regulated learning and college readiness (Hattie, 2013; Shea, \& Bidjerano, 2010; Zimmerman, 1999, 2000, 2002). This case study provided an example of how a blended learning opportunity can increase self-regulation, boost inquiry, and help students, as one student participant noted, feel "more confident going into college." 


\section{References}

Allen, I. E., \& Seaman, J. (2015). Grade level: Tracking online education in the United States. Babson Park, MA: Babson Survey Research Group.

Babbie, E. (1973). Survey research methods. Belmont, CA: Wadsworth.

Barnard, L., Lan, W. Y., To, Y. M., Paton, V. O., \& Lai, S. L. (2009). Measuring self-regulation in online and blended learning environments. The Internet and Higher Education, 12, 1-6.

Basham, J. D., Hall, T. E., Carter, R. A., Jr. \& Stahl, W. M. (2016) An operationalized understanding of personalized learning. Journal of Special Education Technology, 31(3), 126-136.

Bestcolleges.com. (2016). 2016 online education trends: Tracking the innovations and issues changing higher education. Retrieved from http://www.bestcolleges.com/wpcontent/uploads/2016-trends-in-online-education.pdf.

Clayton Christensen Institute for Disruptive Innovation. (2016). Blended learning. Retrieved from http://www.christenseninstitute.org/blended-learning/

Cicchetti, D. V. (1994). Guidelines, criteria, and rules of thumb for evaluating normed and standardized assessment instruments in psychology. Psychological Assessment 6(4), 284-90.

Cole, R. W. (2008). Educating everybody's children: diverse teaching strategies for diverse learners. Rev. and expanded 2nd ed. Alexandria, VA: Association for Supervision and Curriculum Development.

Effeney, G., Carroll, A., \& Bahr, N. (2013). Self-regulated learning and executive function: Exploring the relationships in a sample of adolescent males. Educational Psychology, 33(7), 773-796. doi:10.1080/01443410.2013.785054.

Garrison, R. \& Kanuka, H. (2004). Blended learning: Uncovering it transformative potential in higher education. The Internet and Higher Education, 7(2), 95-105.

Garrett Dikkers, A., Whiteside, A. L., \& Lewis, S. (2017). Blending face-to-face and online instruction to disrupt learning, inspire reflection, and create space for innovation. In A. Whiteside, A. Garrett Dikkers, \& K. Swan (Eds.), Social presence in online learning: Multiple perspectives on practice and research. Sterling, VA: Stylus Publishing.

Garrett Dikkers, A., Whiteside, A. L., \& Lewis, S. (2014, December). Do you blend? Huntley High School does. eLearn Magazine, 2014(12). doi:10.1145/2693839.2686759 
Halverson, L. R., Graham, C. R., Spring, K. J., \& Drysdale, J. S. (2012). An analysis of high impact scholarship and publication trends in blended learning. Distance Education, 33(3), 381-413.

Hattie, J. (2013). Calibration and confidence: Where to next? Learning and Instruction, 24, 62-66.

Lee, C-H., Yeh, D., Kung, R. J., \& Hsu, C-S., (2007). The influences of learning portfolios and attitudes on learning effects in blended e-learning for mathematics. Journal of Educational Computing Research, 37(4), 331-350.

Lee, T. H., Shen, P. D., Tsai, C. W. (2010). Enhance students' computing skills via webmediated self-regulated learning with feedback in blended environment. International Journal of Technology and Human Interaction 6(1), 15-32.

Lewis, S. \& Garrett Dikkers, A. (2016). Professional development supports for the blended, cotaught classroom. Journal of Online Learning Research, 2(2), 103-121.

Means, B., Toyama, Y., \& Murphy, R., Bakia, M., \& Jones, K. (2010). Evaluation of evidencebased practices in online learning: A meta-analysis and review of online learning studies. U. S. Department of Education. Retrieved from http://eric.ed.gov/?id=ED505824

Moore, M. (1997). Theory of transactional distance. In D. Keegan (Ed.), Theoretical principles of distance education (pp. 22-38). New York: Routledge.

Nicol, D., \& Macfarlane-Dick, D. (2006). Formative assessment and self-regulated learning: A model and seven principles of good feedback practice. Studies in Higher Education, 31(2), 199-218.

Orhan, F. (2007). Applying self-regulated learning strategies in a blended learning instruction. World Applied Sciences Journal, 2(4), 390-398.

Pace, J. R. \& Mellard, D. F. (2016). Reading achievement and reading efficacy changes for middle school students with disabilities through blended learning instruction. Journal of Special Education Technology, 31(3), 156-169.

Parks, R. A., Oliver, W., \& Carson, E. (2016). The status of middle and high school instruction: Examining professional development, social desirability, and teacher readiness for blended pedagogy in the southeastern United States. Journal of Online Learning Research, 2(2), 79-101.

Picciano, A.G. (2002). Beyond student perceptions: Issues of interaction, presence, and performance in an online course. Journal of Asynchronous Learning Networks, 6(1), 21-40.

Picciano, A. G. \& Seaman, J. (2009). K-12 online learning: A 2008 follow-up of the survey of U.S. school district administrators. NY: The Sloan Consortium. Retrieved from 


\section{http://www.sloanconsortium.org/publications/survey/k-12online2008.}

Picciano, A.G. \& Seaman, J. (2010). Class connections: High school reform and the role of online learning. Boston, MA: Babson College Survey Research Group.

Pintrich, P., \& Garcia, T. (1994). Self-regulated learning in college students: Knowledge, strategies, and motivation. In P. R. Pintrich, D. Brown, and C. Weinstein (Eds.), Student motivation, cognition, and learning: Essays in honor of Wilbert J. McKeachie, Hillsdale, NJ: Lawrence Erlbaum Associates.

Pintrich, P., \& Zusho, A. (2002). The development of academic self-regulation: The role of cognitive and motivational factors. In A. Wigfield \& J. Eccles (Eds.), Development of achievement motivation. San Diego, CA: Academic Press.

Powell, A., Watson, J., Staley, P., Patrick, S., Horn, M., Fetzer, L., Hibbard, L., Oglesby, J. \& Verma, S. (2015). Blended learning: The evolution of online and face-to-face education from 2008-2015. International Association for K-12 Online Learning.

Riel, J., Lawless, K., \& Brown, S. W., (2016). Listening to the teachers: Using weekly online teacher logs for ROPD to identify teachers' persistent challenges when implementing a blended learning curriculum. Journal of Online Learning Research, 2(2), 169-200.

Ryan, R., \& Deci, E. (2000). Self-determination theory and the facilitation of intrinsic motivation, social development, and well being. American Psychologist, 55(1), 68-78.

Schunk, D. H., \& Ertmer, P. A. (2000). Self-regulation and academic learning: self-efficacy enhancing interventions. In M. Boekaerts, P. R. Pintrich, \& M. Zeidner (Eds.), Handbook of self-regulation (pp. 631-649). San Diego: Academic Press.

Shea, P., \& Bidjerano, T. (2010). Learning presence: Towards a theory of self-efficacy, selfregulation, and the development of a communities of inquiry in online and blended learning environments. Computers \& Education, 55(1), 1721-1731.

U.S. Department of Education, Office of Vocational and Adult Education (2011). Just Write! Guide. Washington, D.C: U.S. Department of Education, Office of Vocational and Adult Education.

Wayer, N., Crippen, K., \& Dawson, K. (2015). Design and enactment of online components during four blended learning courses. Journal of Online Learning Research 1(2), 219239.

Weimer, M. (2009) What it means to be a self-regulated learner. The Teaching Professor. Retrieved from www.facultyfocus.com/articles/teaching-and-learning/what-it-means-tobe-a-self-regulated-learner/ 
Wolters, C. A. (1999). The relation between high school students' motivational regulation and their use of learning strategies, effort, and classroom performance. Learning and Individual Differences, 11(3), 281-301.

Yin, R. (2009). Case study research: Design and methods. 4th ed., London: Sage.

Zimmerman, B. (1990). Self-regulated learning and academic achievement: An overview. Educational Psychologist, 25(1), 3-17.

Zimmerman, B. (2000). Self-efficacy: An essential motive to learn. Educational Psychology, 25, 82-91.

Zimmerman, B. (2002). Becoming a self-regulated learner: An overview. Theory into Practice, 41(2), 64-70. 


\section{Appendix A: Coding Scheme}

\begin{tabular}{|c|c|c|}
\hline SRL Phase & Code & Definition \\
\hline \multicolumn{3}{|c|}{ Forethought Phase } \\
\hline & Blended Readiness & $\begin{array}{l}\text { Refers to level of readiness and preparedness for blended } \\
\text { learning coursework. Can be positive or negative. }\end{array}$ \\
\hline & Community/Relationships & $\begin{array}{l}\text { Any reference to support through each other or any } \\
\text { combination of administrators, teachers, students, and parents. } \\
\text { Also include any references to closeness and communication } \\
\text { - as a strength or weakness. }\end{array}$ \\
\hline & Flexibility & $\begin{array}{l}\text { Refers to the flexibility blended allows or to how flex time is } \\
\text { used. }\end{array}$ \\
\hline & Newness/Pioneers & $\begin{array}{l}\text { References to themselves as being guinea pigs or references } \\
\text { the newness of the program or trying something new. }\end{array}$ \\
\hline & Stronger Teachers/People & $\begin{array}{l}\text { Any reference to teachers/admins/students being stronger in } \\
\text { their role or better teachers because of planning blended } \\
\text { coursework. Might refer to changing or transforming learning. }\end{array}$ \\
\hline \multicolumn{3}{|c|}{ Performance Phase } \\
\hline & Content & $\begin{array}{l}\text { Any reference to a specific course. Or any reference to how } \\
\text { the type of course matters when selecting what should be } \\
\text { taught in a blended format. }\end{array}$ \\
\hline & Responsibility & $\begin{array}{l}\text { Any reference to gaining a sense of responsibility through } \\
\text { blended coursework }\end{array}$ \\
\hline & Tech Literacy & $\begin{array}{l}\text { Any specific reference to how technology is used with the } \\
\text { course content or how a teacher integrates technology in a } \\
\text { meaningful way. Also code for criticisms of blended learning, } \\
\text { e.g., technology for technology’s sake, throwing an iPad in } \\
\text { their hands doesn’t make a difference. } \\
\text { Refers to gaining } 21^{\text {st }} \text { Century skills and technology literacy. } \\
\text { Or, might be a student disclosing how they improve their } \\
\text { technology literacy and communication skills. Code when a } \\
\text { student/teacher/admin/parent mentions technology in a } \\
\text { blended course for communication. }\end{array}$ \\
\hline & Time Management & $\begin{array}{l}\text { Any reference to project or time management - how to } \\
\text { manage time, procrastination, etc. }\end{array}$ \\
\hline \multicolumn{3}{|c|}{ Self-Reflection Phase } \\
\hline & College Readiness & $\begin{array}{l}\text { References to blended as preparation for the future or for } \\
\text { college. }\end{array}$ \\
\hline & Criticisms & $\begin{array}{l}\text { Any criticism of blended learning. Could be a student saying } \\
\text { "not for me” or that something new is not necessarily better. } \\
\text { Could also be more neutral—anything that isn't a glowing } \\
\text { endorsement for the blended initiative. Will likely be double } \\
\text { (or triple, etc.) coded with the other themes in this codebook } \\
\text { (e.g., Tech Integration, Newness/Pioneers, Time } \\
\text { Management). Use this code when a parent/teacher/student } \\
\text { indicates they do not have the orientation or skill set for } \\
\text { blended. }\end{array}$ \\
\hline
\end{tabular}




\section{Appendix B: Coding Examples}

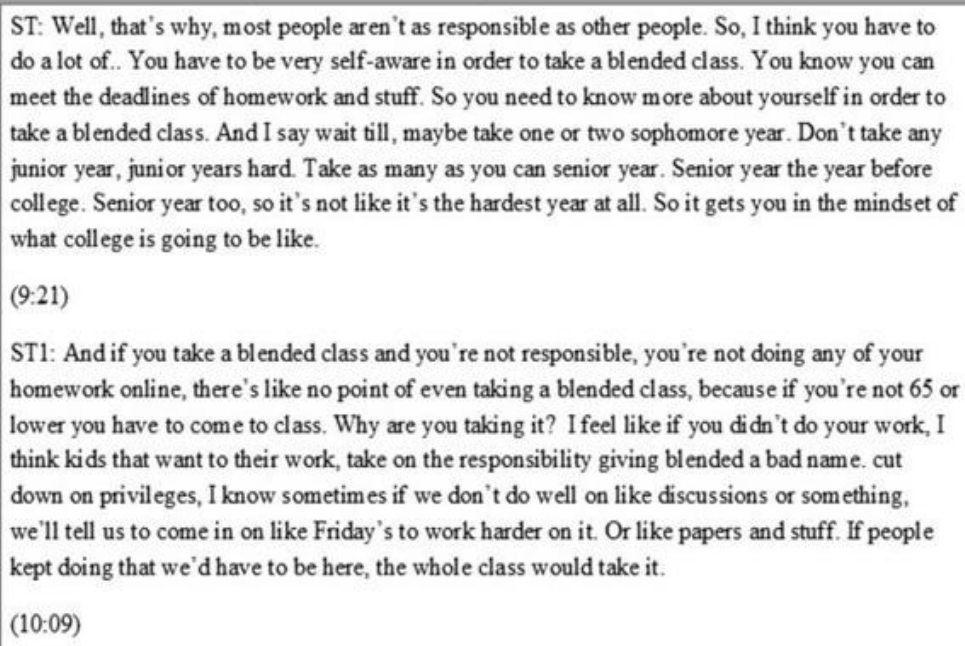

ST1: And if you take a blended class and you're not responsible, you're not doing any of your homework online, there's like no point of even taking a blended class, because if you're not 65 or lower you have to come to class. Why are you taking it? I feel like if you didn't do your work, I think kids that want to their work, take on the responsibility giving blended a bad name. cut down on privileges, I know sometimes if we don't do well on like discussions or something, we'll tell us to come in on like Friday's to work harder on it. Or like papers and stuff. If people kept doing that we' $d$ have to be here, the whole class would take it.

10:44 (Unidentified) It saves time.

10:45 (Unidentified) It saves a lot of time.

10:47 (Unidentified) That's actually why I took this class is cause I wanted to prepare myself for the future where I'd be on my own and having to manage my time properly, so I figured if I tried really hard and do well in this class because I'm doing most of it out - not in the class, then it would make me feel a little more confident going into college.

11:08 (Unidentified) Yeah, I feel like it really benefits especially if you're a junior or a senior taking blended courses it really benefits you a lot because college classes are all structured really similarly to this where you only show up to class two days a week or three days a week and then you do the rest of the work online or outside of class and then you come back to class prepared with everything that you're supposed to have done and it's structured the same way, so if you're a junior or a senior, you're really getting prepared for how college life is going to be. I think that's a big benefit.

11:40 (Moderator) What do you think?

11:41 (Unidentified) I agree with that. I think it gets you ready for college. Regular traditional classes, you're not gonna, in college, the teacher isn't going to stand there and go through power points every single day...

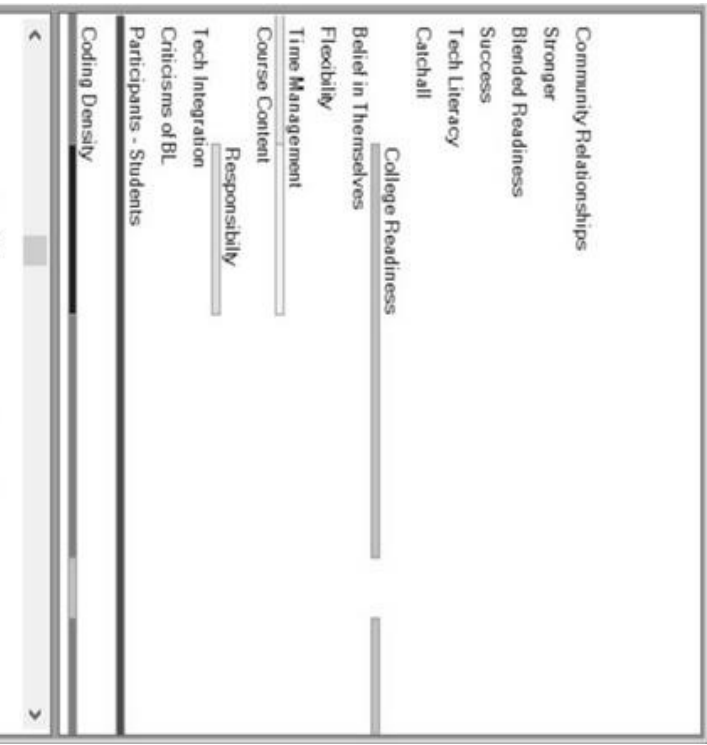

